\title{
A Conceptual Model Of Entrepreneurship: From Perspective To Opportunity
}

\author{
Dotty Wimpertiwi ${ }^{1}$, Christian Haposan Pangaribuan ${ }^{2}$ \\ Department of Management, Binus University, Jakarta, Indonesia ${ }^{1}$ \\ Faculty of Business, Sampoerna University, Jakarta, Indonesia ${ }^{2}$ \\ dotty.wimpertiwi@binus.ac.id ${ }^{1}$, christian.pangaribuan@sampoernauniversity.ac.id ${ }^{2}$
}

\begin{abstract}
This study discusses the activities in two major parts, namely the entrepreneurial perspective and from ideas to opportunities with literature search methods. Contains definitions and their effects about entrepreneurship, which contribute to the research area of entrepreneurship to reinforce previous studies, and are useful for future entrepreneurial research and the academic world who want to teach about understanding or definition. Using Literature Review approach taken from journals and books on entrepreneurship.
\end{abstract}

Keywords: Entrepreneurship, Entrepreneurial Perspective, Entrepreneurial Opportunity.

\section{Introduction}

Today, research on entrepreneurship (Entrepreneurship) is widely discussed both in management journals, marketing journals, social journals, and entrepreneurial journals. Not only in the form of journals, but many books on entrepreneurship are discussed starting from textbook books, to popular books containing practical entrepreneurship as a guide to becoming entrepreneurs.

The various contexts discussed begin entrepreneurship for beginners (start-up) [1];[2];[3];[4], entrepreneurship for MSMEs to entrepreneurship for large companies[5];[4]. The scale also varies from local entrepreneurship[6] to entrepreneurship that is global or international [7];[8];[9]. It is not only diverse contexts and scales but the activities carried out in entrepreneurship should be discussed a lot before starting from making ideas to how the efforts made can survive.

Entrepreneurship is divided into 5 parts, namely: 1) entrepreneurial perspective, 2) from ideas to opportunities, 3) from opportunities to business planning, 4 ) from planning to funding, 5) from funding to launching businesses, growing, and ending new businesses[10]. However, in this article discussing entrepreneurship in the literature study is limited to divided into 2 major parts, namely: entrepreneurial perspective and from ideas to opportunities, then discussing related content, its definition and its impact, which contribute to the research area of entrepreneurship to strengthen previous research conceptually. 


\section{Method}

Entrepreneurship plays an important role in the creation and growth of a business. So it becomes important to know what activities are implemented in entrepreneurship. Starting from entrepreneurial activities upstream to downstream. But this paper does not discuss the overall entrepreneurial activities.

\section{Result}

In contrast to research [11] which divides entrepreneurship in 3 major parts, namely looking at entrepreneurship based on the organizational context, performance criteria and entrepreneurial behavior, in this paper discusses entrepreneurship divided into 2 (two) major parts of 4 (four) discussed[10], and each section discusses related entrepreneurial content. Where the description is explained in the following table.

Table 1. Entrepreneurial Activities and Entrepreneurial Topic

\begin{tabular}{|c|c|c|c|}
\hline Entrepreneurial Activities & Entrepreneurial Topic & Definition & Illustration Studies \\
\hline \multirow[t]{3}{*}{ Entrepreneurial Perspective } & Entrepreneurial Mindset & $\begin{array}{l}\text { The entrepreneur's mindset in making } \\
\text { decisions sometimes has to think } \\
\text { structured / systematically, with } \\
\text { regard to bricolage or in other words } \\
\text { make a decision by making a } \\
\text { combination of resources that remain } \\
\text { owned, effectual or process with } \\
\text { regard to what is owned, } \\
\text { adaptability[10]. }\end{array}$ & [12], \\
\hline & $\begin{array}{l}\text { Entrepreneurial } \\
\text { Orientation }\end{array}$ & $\begin{array}{l}\text { Related to the intention to apply using } \\
\text { entrepreneurial principles, which are } \\
\text { related to behavior, to get desired } \\
\text { performance have competitive } \\
\text { advantages, to maintain their } \\
\text { business[13]. } \\
\text { Sometimes it is associated with other } \\
\text { things such as religion [14]. }\end{array}$ & [13], [15]-[17]. \\
\hline & $\begin{array}{l}\text { Corporate } \\
\text { Entrepreneurship and } \\
\text { Entrepreneurial Strategies }\end{array}$ & $\begin{array}{l}\text { Entrepreneurial actions in established } \\
\text { businesses [10] to innovate faster than } \\
\text { competitors find company resources } \\
{[18] \text { as the capability to find new }} \\
\text { ways, develop new technologies and } \\
\text { products, in entering new markets in } \\
\text { an organization. Or in other words to }\end{array}$ & [21], [22] \\
\hline
\end{tabular}




\begin{tabular}{|c|c|c|c|}
\hline & & $\begin{array}{l}\text { identify and achieve entrepreneurial } \\
\text { opportunities[19]. } \\
\text { The Entrepreneurship Strategy in this } \\
\text { phase is a strategy to enter new } \\
\text { markets to exploit new things for } \\
\text { businesses to achieve competitive } \\
\text { advantage, judging from the initial } \\
\text { steps[10]. } \\
\text { Entrepreneurial strategies are also } \\
\text { needed by the company to the next } \\
\text { level, namely to achieve lasting } \\
\text { excellence[20]. }\end{array}$ & [23]-[26] \\
\hline & $\begin{array}{l}\text { Entrepreneurial Intention } \\
\text { and Cognition }\end{array}$ & $\begin{array}{l}\text { Motivational factors that influence } \\
\text { individuals to achieve entrepreneurial } \\
\text { results [24]. }\end{array}$ & {$[27],[28]$} \\
\hline \multirow[t]{2}{*}{$\begin{array}{l}\text { From Ideas to } \\
\text { Opportunities }\end{array}$} & $\begin{array}{l}\text { Creativity and } \\
\text { Entrepreneurship }\end{array}$ & $\begin{array}{l}\text { Creativity is an important attribute } \\
\text { needed for important entrepreneurs by } \\
\text { looking at individual potential } \\
\text { through perceptual, cultural, } \\
\text { emotional and organizational } \\
\text { factors[10]. }\end{array}$ & [27], [28] \\
\hline & $\begin{array}{l}\text { The Culture that affects } \\
\text { Entrepreneurship }\end{array}$ & $\begin{array}{l}\text { Culture has been defined by } \\
\text { anthropologists [10] have } 160 \\
\text { different meanings, but in general, } \\
\text { culture is a way of thinking and } \\
\text { behaving from parents to children or } \\
\text { transmitted through social } \\
\text { organizations, developed, and } \\
\text { strengthened through social pressure. } \\
\text { Culture is also an individual or } \\
\text { community identity[10]. }\end{array}$ & [30] \\
\hline
\end{tabular}




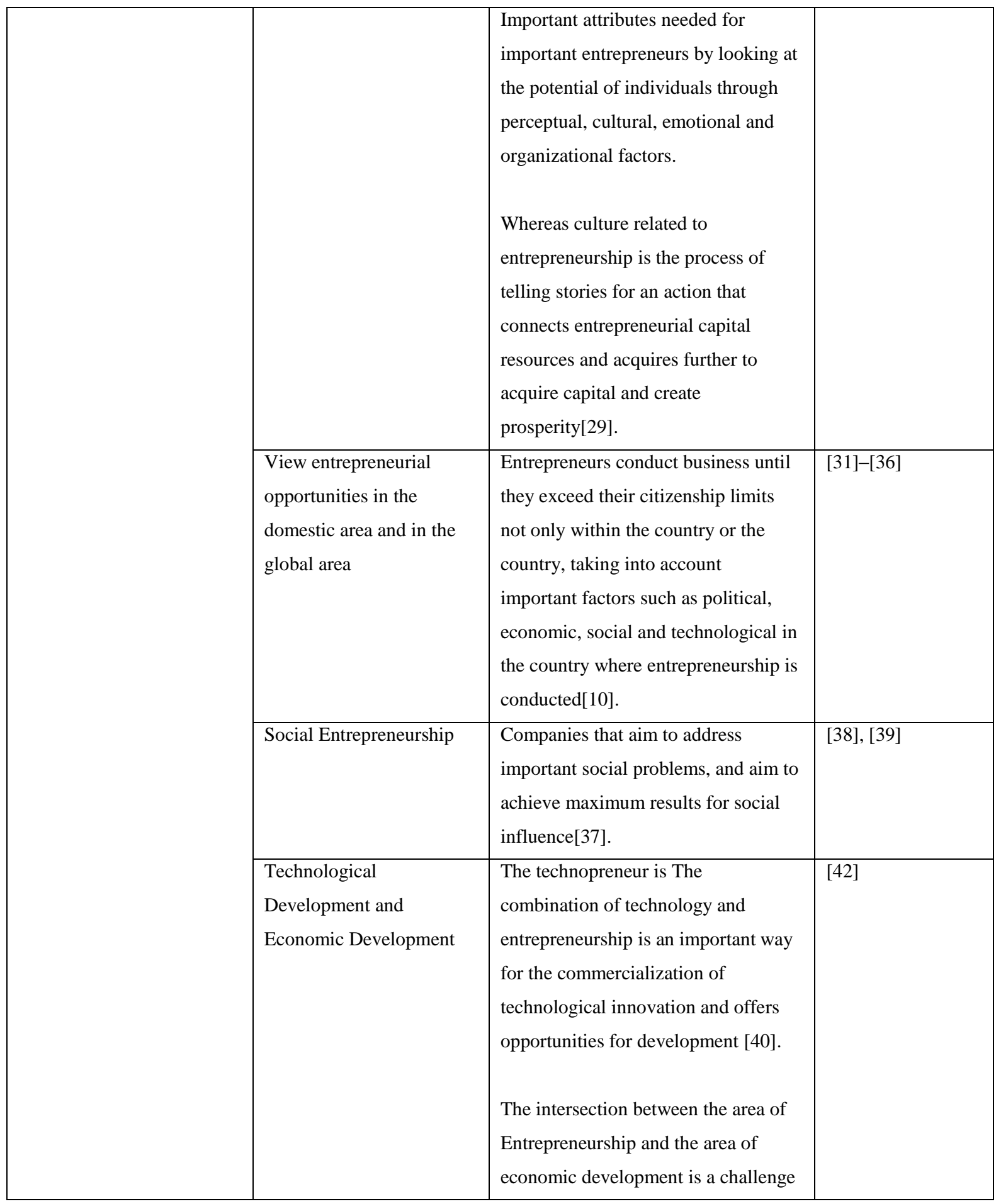




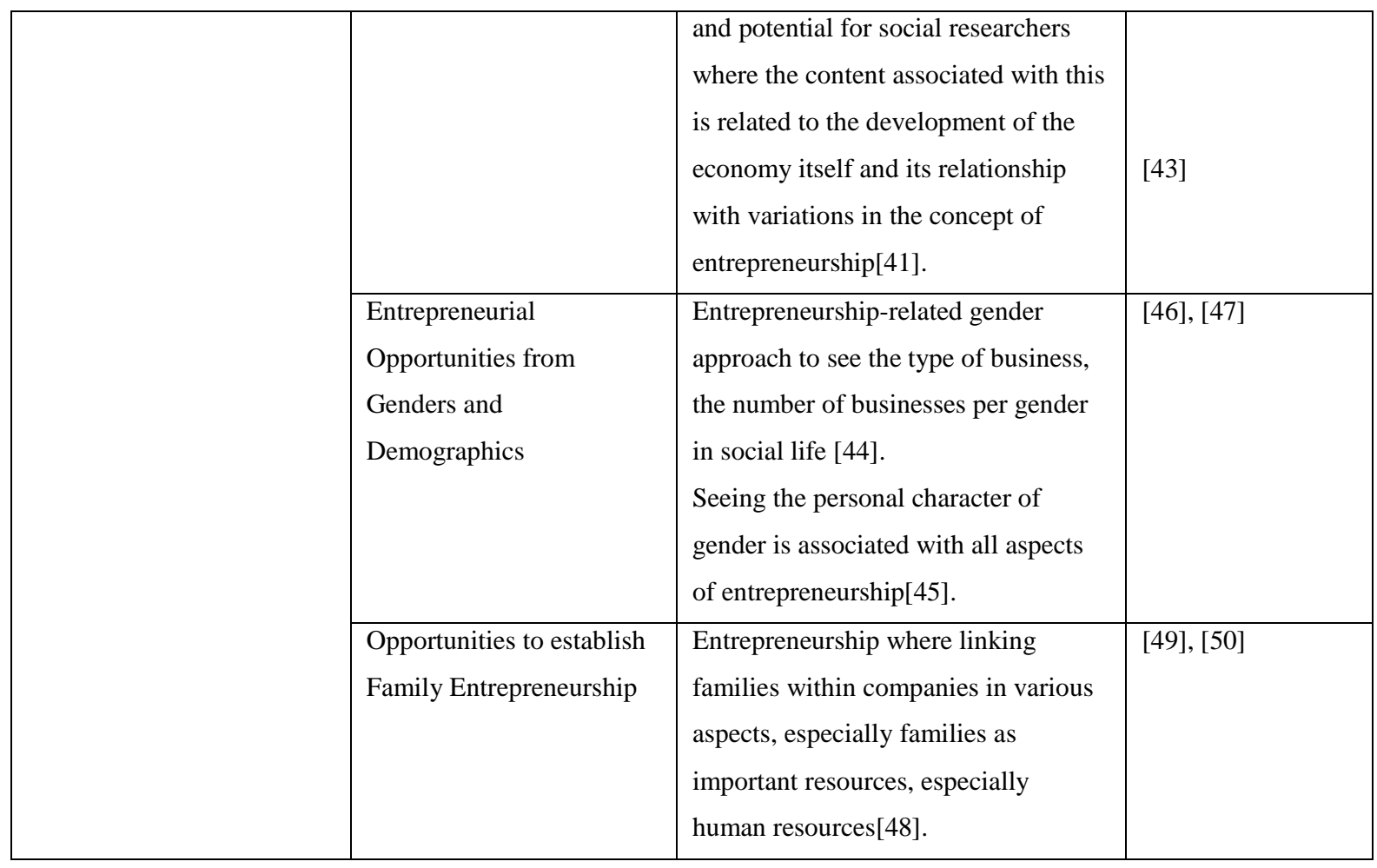

\section{Discussion}

\subsection{Entrepreneurship Perspective}

Undergo entrepreneurship by becoming a different entrepreneur from non-entrepreneurs. One thing that makes a difference is that entrepreneurs must have an entrepreneurial perspective or entrepreneurial perspective that is not owned by non-entrepreneurs.

This perspective can be seen from a structured or systematic entrepreneurial mindset [51] related to ideas, management of resources owned, to the creation process. Then the perspective can be seen from entrepreneurial intentions or the motivation of an entrepreneur in carrying out entrepreneurial[52].Then the intention is added by the presence of an innovative attitude, risktaking, proactivity, autonomy, and others called entrepreneurial orientation [14];[53];[54];[55].

This perspective is an added value for an entrepreneur to succeed in his business. The measure of success is its performance in the form of financial and non-financial performance, the continuity of its business, and its efforts to become large, becoming a large and wellestablished company, called corporate entrepreneurship[10].For this reason, an entrepreneurial strategy is needed where the strategy needed in this phase is a strategy to enter new markets to exploit new things for businesses to achieve competitive advantage [10].

\subsection{From Ideas to Opportunity}

In entrepreneurship, just having a good idea is not enough but must be developed through various ways with creativity, innovation and seeing opportunities that exist from various aspects. 
The importance of creativity and innovation in a dynamic market, where the combination of production factors is the essence of innovation[56]. The impact of innovation on companies is diverse, including the impact on performance [57] , the sustainability of a company [58] and create an advantage that competitive[59]. Creativity is also important for an entrepreneur because it is an important attribute that is needed, by looking at individual potential through perceptual, cultural, emotional and organizational factors [10]. Then a good creativity and innovation are creativity and innovation that are manifested in the form of entrepreneurial activities or activities. These activities will later create a new product and/or process and or enter a new market opportunity, with a newly formed or existing organization[10]. The activities or actions of entrepreneurs on what is believed are what are called opportunities. Because doing entrepreneurship is the same as carrying out activities filled with uncertainty or high risk.

As is already known entrepreneurial opportunities if, in terms of regional demographics, the scope can be local, national or can even extend to international so-called international entrepreneurship. International Entrepreneurship operates at the borders between groups, where most of its entrepreneurship cannot be seen in the creation of a new business, goods or services which previously did not exist.

And to better understand international entrepreneurship as well as an international entrepreneur, it can be more competitive to introduce a method to understand an entrepreneurial process through a framework of Comparative, Discovery, Evaluation, and Exploitation (CDEE) [60]. Several studies have discussed a lot about international entrepreneurship and several factors associated with it. Among other things, International entrepreneurship depends on its geographical location, relates it to the social ties of the company, and companies that have high social ties enhance experience internationally[61].

The company's opportunity to penetrate to international or global is not only a large company, but MSME businesses can also spread to the international through research[62];[63];[64]. Not only regional demographic factors that can be an opportunity in establishing an entrepreneur. But gender or gender factors can also be opportunities that can be seen to set up a business[45].

An opportunity can also come from the field of technology, becoming a technopreneur[40], or also establishing a social entrepreneurship [37] establishing a business that has a social impact, or can also establishing businesses with families as their main resource [65].

\section{Conclusion}

As stated above, there is a lot of research on entrepreneurship in the form of journals and written in books. Both conceptual and empirical research, both about theory, definitions, and their implications in the world of entrepreneurship. Predecessor theories that predominantly underlie entrepreneurial research. These theories are an economic theory, human resource theory, psychological theory, sociology theory, and anthropological theory[66].

Then there is divides entrepreneurship into 1) entrepreneurship as an organizational context, for example from size, age, individual ownership to family, 2) entrepreneurship based on its performance, which here is based on innovation or growth, 3) entrepreneurship based on behavior, see the behavior of entrepreneurial orientation based on entrepreneurial opportunities[11].

While this paper emphasizes content related to an entrepreneurial activity which is linked to two entrepreneurial activities in general, namely the entrepreneurial perspective and from ideas to opportunities. Which can strengthen previous entrepreneurial studies and be useful for academically in teaching the entrepreneurial material, because here describes the definition and implications in the world of entrepreneurship. 
The writing of this paper only limits the content related to any activities carried out in two major parts of the entrepreneurial perspective and from ideas to opportunities by definition and its implications. So it is recommended that further research continue as stated in related content 1) from an opportunity to business planning, 2) from planning to funding, 3) from funding to launching the business, grow, and end new businesses by definition, their impact and implications [10]. And it is also expected that further research will discuss entrepreneurship in a whole process that involves the underlying theory associated with the content or variables involved.

\section{References}

[1] R. F. Bortolini, M. Nogueira Cortimiglia, A. d. M. F. Danilevicz, dan A. Ghezzi, Lean Startup: a Comprehensive Historical Review. Management Decision. 2018.

[2] A. Carsrud, "Study of Young Biotechnology Ventures in the United States and in Scandinavia," J. Small Bus. Manag., vol. 47, no. 3, hlm. 331-369, 2009.

[3] W. Frick, "Economy," 2016.

[4] E. Yoon dan S. Hughes, "Big Companies Should Collaborate with Startups," Harv. Bus. Rev., hlm. 1-6, 2016.

[5] F. J. Sáez-Martínez, C. Díaz-García, dan A. Gonzalez-Moreno, "Firm Technological Trajectory As a Driver Of Eco-Innovation In Young Small And Medium-Sized Enterprises," J. Clean. Prod., vol. 138, hlm. 28-37, 2016.

[6] A. Rodríguez-Pose dan D. Hardy, "Firm Competitiveness and Regional Disparities In Georgia," Geogr. Rev., vol. 107, no. 2, hlm. 384-411, 2017.

[7] R. Caiazza dan T. Volpe, "How Campanian Small and Medium Enterprises (SMEs) Can Compete in the Global Agro-Food Industry," J. Food Prod. Mark., vol. 19, no. 5, hlm. 406-412, 2013.

[8] A. Hira, J. Morfopoulos, dan F. Chee, "Evolution Of The South Korean Wireless Industry: From State Guidance To Global Competition," Int. J. Technol. Glob., vol. 6, no. 1/2, hlm. 65, 2012.

[9] E. Nemkova, "The Impact Of Agility On the Market Performance Of Born-Global Firms: An Exploratory Study Of The 'Tech City' Innovation Cluster,' J. Bus. Res., vol. 80, no. 2016, hlm. 257-265, 2017.

[10] R. D.Hisrich, M. P.Peter, dan D. A.Shepperd, New York: Mc Graw Hill Education, 2017.

[11] D. Audretsch, Entrep. Res., vol. 50, no. 5, hlm. 755-764, 2012.

[12] R. Garud dan P. Karnoe, "Bricolage vs. breakthrough: distributed and embedded ageny in technology entrepreneurship," Res. Policy, vol. 32, no. 2, hlm. 277-300, 2003.

[13] P. Shan, M. Song, dan X. Ju, "Entrepreneurial orientation and performance : Is innovation speed a missing link?,” J. Bus. Res., 2015.

[14] J. A. Pearce, D. A. Fritz, dan P. S. Davis, "Entrepreneurial Orientation and The Performance Of Religious Congregations As Predicted By Rational Choice Theory," Entrep. Theory Pract., vol. 34, no. 1, hlm. 219-248, 2010.

[15] A. Rauch, J. Wiklund, G. T. Lumpkin, dan M. Frese, "Entrepreneurial orientation and business performance: An assessment of past research and suggestions for the future," Entrep. Theory Pract., vol. 33, no. 3, hlm. 761-787, 2009.

[16] W. Stam dan T. O. M. Elfring, "Entrepreneurial Orientation and New Venture Performance : the Moderating Role of Intra- and Extraindustry Social Capital," vol. 51, no. 1, hlm. 97-111, 2004. 
[17] J. A. Pearce, D. A. Fritz, dan P. S. Davis, "Entrepreneurial orientation and the performance of religious congregations as predicted by rational choice theory," Entrep. Theory Pract., vol. 34, no. 1, hlm. 219-248, 2010.

[18] B. S. Teng, "Corporate Entrepreneurship Activities Through Strategic Alliances: A Resource-Based Approach Toward Competitive Advantage," J. Manag. Stud., vol. 44, no. 1, hlm. 119-142, 2007.

[19] P. Sharma dan J. J. Chrisman, "Toward A Reconcilation Of The Definitional Issues In Teh Field Of Corporate Entrepreneurship," Entrep. Theory Pract., vol. 23, no. 3, hlm. 11-28, 1999.

[20] R. D. Ireland dan M. A. Hitt, "Achieving And Maintaining Strategic Competitiveness In The 21st Century: The Role Of Strategic Leadership," Acad. Manag. Perspect., vol. 13, no. 1, hlm. 43-57, Feb 1999.

[21] B. S. Teng, "Corporate entrepreneurship activities through strategic alliances: A resourcebased approach toward competitive advantage," J. Manag. Stud., vol. 44, no. 1, hlm. 119142, 2007.

[22] P. Sharma dan J. J. Chrisman, "Toward a reconcilation of the definitional issues in teh field of corporate entrepreneurship," Entrep. Theory Pract., vol. 23, no. 3, hlm. 11-28, 1999.

[23] T. Lee dan W. Chu, "Journal of Family Business Strategy The relationship between entrepreneurial orientation and fi rm performance : In fl uence of family governance," no. xxxx, 2017.

[24] R. D. Ireland, M. A. Hitt, dan D. G. Sirmon, "A model of strategic enterpreneurship: The construct and its dimensions," J. Manag., vol. 29, no. 6, hlm. 963-989, 2003.

[25] R. A. Burgelman, "Corporate Entrepreneurship and Strategic Management: Insights from a Process Study,” Manag. Sci., vol. 29, no. 12, hlm. 1349-1364, 1983.

[26] M. A. Hitt, R. D. Ireland, S. M. Camp, dan D. L. Sexton, "Strategic entrepreneurship: entrepreneurial strategies for wealth creation," Strateg. Manag. J., vol. 22, no. 6-7, hlm. 479-491, 2001.

[27] M. Baer, "The Strength-of-Weak-Ties Perspective on Creativity: A Comprehensive Examination and Extension," J. Appl. Psychol., vol. 95, no. 3, hlm. 592-601, 2010.

[28] P. F. Skilton dan K. J. Dooley, "The effects of repeat collaboration on creative Abrasion," Acad. Manage. Rev., vol. 35, no. 1, hlm. 118-134, 2010.

[29] M. Lounsbury dan M. A. Glynn, "Cultural Entrepreneurship : Stories, Legitimacy , And The Acquisition Of Resources,” Strateg. Manag. J., vol. 564, hlm. 545-564, 2001

[30] M. Lounsbury dan M. A. Glynn, "CULTURAL ENTREPRENEURSHIP : STORIES , LEGITIMACY , AND THE ACQUISITION OF RESOURCES,” Strateg. Manag. J., vol. 564, hlm. 545-564, 2001.

[31] H. J. Sapienza dan J. G. Almeida, “The Internationalization of Entrepreneurship,” J. Int. Bus. Stud., vol. 36, no. Jan, hlm. 61-77, 1997.

[32] T. Baker, E. Gedajlovic, dan M. Lubatkin, "A framework for comparing entrepreneurs processes across nations," J. Int. Bus. Stud., vol. 36, no. 5, hlm. 492-504, 2016.

[33] P. Ellis, "Social ties and international entrepreneurship," J. Int. Bus. Stud., vol. 42, no. 1, hlm. p99-127, 2011.

[34] A. Kauppinen dan A. Juho, "Internationalisation of SMEs from the perspective of social learning theory," J. Int. Entrep., vol. 10, no. 3, hlm. 200-231, 2012.

[35] R. K. Singh, S. K. Garg, dan S. G. Deshmukh, "The competitiveness of SMEs in a globalized economy Observations from China and India," 2002. 
[36] M. Á. Rodríguez-Serrano dan E. Martín-Armario, "Born-Global SMEs, Performance, and Dynamic Absorptive Capacity: Evidence from Spanish Firms,” J. Small Bus. Manag., vol. 00, no. 00, 2017.

[37] M. Gray dan P. Crofts, Social Entrepreneurship and its Implications for Social Work, vol. 1. 2002.

[38] M. J. Simonette $d k k$., "Efetividade Do Processo De Comunicação Com Base Na Teoria Do Comportamento Informacional: O Caso De Um Organismo Internacional Da Área Da Saúde Pública Sediado No Brasil," Syst. Res. Behav. Sci., vol. 8, no. 3, hlm. 27-42, 2008.

[39] M. Gray dan P. Crofts, "Social Entrepreneurship and its implications for social work 1," vol. 12, no. August 2001, hlm. 1-27, 2002.

[40] A. Mirchev dan V. Dicheva, "Technological Entrepreneurship of Small and Medium," dalam Business in the Republic of Bulgaria As, 2013, hlm. 91-96.

[41] W. Naude, "Entrepreneurship and Economic Development," 2011.

[42] A. Mirchev dan V. Dicheva, "Technological Entrepreneurship of Small and Medium Business in the Republic of Bulgaria As," hlm. 91-96, 2013.

[43] W. Naude, Entrepreneurship and Economic Development. 2011.

[44] N. Harding, A. Bruni, S. Gherardi, dan B. Poggio, Gender and Entrepreneurship, vol. eLibrary. New York: Taylor \& Francis, 2008.

[45] B. E. Duffy dan U. Pruchniewska, "Gender and Self-Enterprise In The Social Media Age: a Digital Double Bind," Inf. Commun. Soc., vol. 20, no. 6, hlm. 843-859, 2017.

[46] I. Verheul, L. Uhlaner, dan R. Thurik, Business accomplishments, gender and entrepreneurial self-image, vol. 20. 2005.

[47] N. Harding, A. Bruni, S. Gherardi, dan B. Poggio, Gender and Entrepreneurship. New York: Taylor \& Francis e-Library, 2008.

[48] C. Howorth, M. Rose, dan E. Hamilton, "Definitions, Diversity and Development: Key Debates in Family," Bus. Res. Oxf. Handb. Entrep., hlm. 1-25, Jun 2009.

[49] M. Bertrand dan A. Schoar, "The Role of Family in Family Firms," J. Econ. Perspect., vol. 20, no. 2, hlm. 73-96, 2006.

[50] C. Howorth, M. Rose, dan E. Hamilton, "Definitions, Diversity and Development: Key Debates in Family Business Research," Oxf. Handb. Entrep., no. June 2018, hlm. 1-25, 2009.

[51] R. Garud dan P. Karnoe, "Bricolage vs. Breakthrough: Distributed and Embedded Ageny in Technology Entrepreneurship," Res. Policy, vol. 32, no. 2, hlm. 277-300, 2003.

[52] M. Baer, "The Strength-of-Weak-Ties Perspective on Creativity: A Comprehensive Examination and Extension," J. Appl. Psychol., vol. 95, no. 3, hlm. 592-601, 2010.

[53] A. Rauch, J. Wiklund, G. T. Lumpkin, dan M. Frese, "Entrepreneurial Orientation and Business Performance: An Assessment Of Past Research and Suggestions For the Future," Entrep. Theory Pract., vol. 33, no. 3, hlm. 761-787, 2009.

[54] P. Shan, M. Song, dan X. Ju, "Entrepreneurial Orientation And Performance: Is Innovation Speed A Missing Link ?," J. Bus. Res., 2015.

[55] W. Stam dan T. O. M. Elfring, "Entrepreneurial Orientation and New Venture Performance : the Moderating Role of Intra-," Extr. Soc. Cap., vol. 51, no. 1, hlm. 97 111, 2004.

[56] J. Schumpeter, Capitalism, Socialism and Democracy. New York: Harper and Row, 1942.

[57] S. Naja, Z. Naja, P. Naudé, P. Oghazi, dan E. Zeynaloo, How Collaborative Innovation Networks A Ff Ect New Product Performance : Product Innovation Capability, Process Innovation Capability, And Absorptive Capacity. Industrial Marketing Management. 2018. 
[58] S. Schaltegger, F. Lüdeke-Freund, dan E. G. Hansen, "Business Cases For Sustainability: The Role Of Business Model Innovation For Corporate Sustainability," Int. J. Innov. Sustain. Dev., vol. 6, no. 2, hlm. 95-119, 2012.

[59] G. Shqipe dan R. V. Rexhepi Gadaf, "Inovation Strategies and Competitive," dalam advantages, vol. 8, 2013, hlm. 10-23.

[60] T. Baker, E. Gedajlovic, dan M. Lubatkin, "A Framework For Comparing Entrepreneurs Processes Across Nations," J. Int. Bus. Stud., vol. 36, no. 5, hlm. 492-504, 2016.

[61] P. Ellis, "Socialities and International Entrepreneurship," J. Int. Bus. Stud., vol. 42, no. 1, hlm. 99-127, 2011.

[62] A. Kauppinen dan A. Juho, "Internationalisation of SMEs From The Perspective Of Social Learning Theory," J. Int. Entrep., vol. 10, no. 3, hlm. 200-231, 2012.

[63] M. Á. Rodríguez-Serrano dan E. Martín-Armario, "Born-Global SMEs, Performance, and Dynamic Absorptive Capacity: Evidence from Spanish Firms,” J. Small Bus. Manag., vol. 0, no. 0, 2017.

[64] R. K. Singh, S. K. Garg, dan S. G. Deshmukh, The Competitiveness Of Smes In A Globalized Economy Observations From China And India. 2002.

[65] M. Bertrand dan A. Schoar, "The Role of Family in Family Firms," J. Econ. Perspect., vol. 20, no. 2, hlm. 73-96, 2006.

[66] L. Raimi, "Discourse Analysis Of Entrepreneurship Definitions and Theories: Implication For Strengthening Academic Research," Int J Entrep. Small Bus., vol. 26, no. 3, hlm. 368, 2015. 
